\title{
On teenage mothers' motivation and determination: Basis for guidance program
}

\author{
Mesa, Ramil D. $\bowtie$ \\ Laguna College of Business and Arts, Philippines (ramstable29@gmail.com)

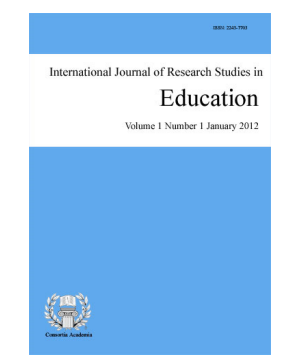

Accepted: 9 August 2021

ISSN: 2243-7703 Online ISSN: 2243-7711

OPEN ACCESS

\section{Abstract}

The main thrust of this study was to look into the lived experience of senior high school teenage mothers. The research design utilized was qualitative with phenomenology as an approach. The data were gathered through interviews among the 5 senior high school students who became mothers at an early age. Using the interpretative phenomenological approach, the study generated eight superordinate themes which were mixed emotions, accepting the situation, negative at first, very unusual, looking at the brighter side, pursuing their dreams, perseverance and commitment, and thinking before doing. The initial reactions upon knowing that they were pregnant was with mixed emotions. It was more of anxiety of what others and their parents' reaction would be and also happy since they would be mothers at a very young age. They dealt with news of unexpected pregnancy. The plans that they would have, most especially with letting their parents know about their situation and the things that they would do in the future were actually a big help for both of them since they had a baby both at a very young age. They had to face all the consequences in life. It was the parents who were curious about their situation since they noticed lots of changes in their daughter. At the same time, after confirming the pregnancy at their age, it was dismaying on the part of the parents. They revealed changes that were actually different and were not experienced until they became pregnant. They made their babies an inspiration. Though mothers at a very young age, they still they had to pursue their dreams and their goals in life. As an output of the study, a guidance program and a social media account was proposed.

Keywords: teenage mothers, motivation, determination, guidance program 


\section{On teenage mothers' motivation and determination: Basis for guidance program}

\section{Introduction}

Teenage mothers remain of interest, as they are more likely than older mothers to experience broader disadvantage because of their younger age, including access to education, employment and social support (AIHW, 2012a; Marino et al., 2016; McArthur \& Barry, 2013). Evidence also shows that babies born to teenage mothers are more likely to be pre-term, of low birthweight and more likely to suffer higher morbidity and mortality (AIHW, 2012a; AIHW, 2016b; Marino et al., 2016). Teenage Pregnancy had been a worldwide issue, and has raised large numbers of campaigns and awareness to lessen its occurrence. The total number of this phenomenon is increasing each year. Philippines is one of the Asian countries which shares similar situation. The incidence of teenage pregnancy has been on the rise in different parts of the world. Teenage pregnancy affects 5.99 percent of Filipino girls which is the second highest rate in Southeast Asia based on Save the Children's Global Childhood Report (2019). According to Philippine Statistics Authority (PSA), an estimated 538 babies are born to Filipino teenage mother every single day. The Philippines is currently problematic due to the increasing number of teenage pregnancies as 13.6 percent of girls below 18-years-old got themselves pregnant in 2018. Worse, nine percent of girls aged between 15 and 19 have already given birth or are pregnant.

According to the study conducted by Lariba (2017), the main causes of teenage pregnancy are poor parenting, parent-teenage relationship, peer pressure, influence, uncontrolled sex feelings, sexual abuse, socio-economic factors, and childhood environment. In addition, causes of dropouts were attributed to parental ignorance of the importance of education, poverty, and other social issues such as teenage pregnancy as stated in World Inequality Databased on Education (WIDE, 2014). According to Kingston (2012), teenage births result in health consequences; children are more likely to be born pre- term, have lower birth weight, and higher neonatal mortality, while mothers experience greater rates of post-partum depression and are less likely to initiate breastfeeding. Moreover, Akella and Jordan (2011) said that mothers and older sisters are the main sources of family influence on teenage pregnancy; this is due to both social risk and social influence. Family members both contribute to an individual's attitudes and values around teenage pregnancy, and share social risks (such as poverty, ethnicity, and lack of opportunities) that influence the likelihood of teenage pregnancy Having an older sister who was a teen mom significantly increases the risk of teenage childbearing in the younger sister and daughters of teenage mothers were significantly more likely to become teenage mothers themselves. (Ferraro, 2013).

Adolescence is the period of transition between childhood and adulthood. It includes some big changes - physical, sexual, cognitive, social, and emotional changes. These changes can bring anticipation and anxiety for both children and their families. However, understanding what to expect at different stages can promote healthy development throughout adolescence and into early adulthood as mentioned by Allen and Waterman (2019). Pregnancy at whatever stage in life can be a life changing experience that cuts across boundaries of race, educational attainment and socio-economic status (Kost et al., 2010). Motherhood places demands on one's life which were hitherto non-existent prior to the birth of the girl child. When a girl that should be in school becomes pregnant, her entire life could be completely altered as her hopes and aspirations could be shattered. The increasing number of teenage mothers got the attention of the researcher. He wants to know the lived experience of these students, the causes or reasons for their early pregnancy, the challenges they faced, the lessons and values they learned from their experience, the big responsibilities that await them, and their future plans after giving birth.

The researcher conducted this study to enlighten the minds of teenage mother that in spite of the big responsibilities they are facing, they have to strive harder to achieve their goals in life for a brighter future. It will also help the participants to guide them and to find out what kind of plan that they are considering before, 
during and after the pregnancy. Getting into this kind of situation is really very hard on the part of the teenage mother.

\subsection{Theoretical framework}

This study will be anchored on the following theories and concepts. First, the Theory of Reasoned Action (ToRA or TRA), developed by Martin Fishbein and IcekAjzen, which assumes the best predictor of behavior is behavioral intention. It is guided by two major constructs. Attitudes are the beliefs and feelings about certain behaviors and the values (positive or negative) attached to the outcome of that behavior according to Fishbein and Ajzen (1975) as mentioned by Montano and Kasprzyk (2008). Subjective norms are the perceptions of social norms, including a belief about whether referent individuals approve or disapprove of a behavior and the individual's motivation to comply with these normative beliefs. This aim to explain the relationship between attitudes and behaviors within human action. It is mainly used to predict how individuals will behave based on their pre-existing attitudes and behavioral intentions.

Second, Kolb's theory which states that the impetus for the development of new concepts is provided by new experiences. "Learning is the process whereby knowledge is created through the transformation of experience" (Kolb, 1984). Kolb's experiential learning style theory is typically represented by a four-stage learning cycle in which the learner 'touches all the bases': Concrete Experience - a new experience or situation is encountered, or a reinterpretation of existing experience. Reflective Observation of the New Experience - of particular importance are any inconsistencies between experience and understanding. Abstract Conceptualization reflection gives rise to a new idea, or a modification of an existing abstract concept (the person has learned from their experience). Active Experimentation - the learner applies their idea(s) to the world around them to see what happens.

For the teenagers and young women who participated in this research, the above dimensions were a central part of their identities. Thus, intersectionality theory goes beyond the boundaries of race and gender to include other social categories such as migration status, religion, sexual orientation, educational attainment, language and many other categories that play and/or influence the individual's life situation. Intersectionality theorists argue that to be able to understand the world of minority women, it is critical to move beyond the boundaries of gender and race. For Sub-Saharan African (SSA) women, culture, marriage, and child bearing remain important. Marriage and childbearing almost often define a woman's position within the family and her community (Ngum, 2012). Using the single axes of either race or gender will not present a complete picture of the individual's experiences and cannot fully answer questions about the woman's existence (Collins, 1990). To understand the position and the experiences of the teenage mothers in this study, their cultural heritage, the community associations and the lives or journeys they have experienced should be considered.

The Theory of Reasoned Action which means that if someone was to evaluate a behavior with a positive attitude and think that significant others like friends, peers, and family want them to perform a behavior, there is a higher intention or motivation to carry out the behavior. This study shows that the accounts of the participants with regards to their experiences, the early pregnancy, established their positive attitude towards the situation that they experienced. The member of their family and friends shared different motivation and encouragement to pursue pregnancy and accept the reality even it is unplanned. It clearly reflects to what kind of behavior the participant has in this kind of situation.

Another theory is the Experiential Learning Theory (Kolb, 1984) which states that the different experiences of the participants shows that they are all encountered a new experience or situation. To get pregnant at their early ages really changed their world. It shows how they cope up with this kind of situation. The four stage of learning cycle define how they handled the situation where in after they found out that they are pregnant, they talked about it, reflect about it then the next step is to find out what they learned from it then after that is the planning, on how to finally move on in this kind of situation. 


\subsection{Central and Corollary Questions}

The proposed study endeavors to describe the lived experience of the teenage mother in the City of Calamba. The researcher wants to find out. the causes or reasons for their early pregnancy, the challenges they faced, the lessons and values they learned from their experience, the big responsibilities that await them, and their future plans after giving birth. The researcher seeks to answer one central question that is -

\section{What is the essence of lived experience of teenage mothers?}

This study also answers the following corollary questions:

$>\quad$ What themes emerged from the testimonies of the teenage mothers?

$>$ Based on the findings, what guidance program can be proposed?

\subsection{Significance of the Study}

The teenage mothers. They may get insights from this study on how they could better cope with their lives as student with an early responsibility as a young mother. Those who are, not by choice but for un-avoidable circumstances get into it and be a guiding principle for them to be aware of what is the real situation in this kind of stage of life.

Students. The findings of this research will enable students to be aware on the situation that they might be encountered once they also experience in anticipation for them to be vigilant and be a responsible senior high school student.

Parents. As guardians, they will also benefit from the study. The findings of this research will make them knowledgeable of the challenges faced by student on how they will provide extra guidance to their daughters specially those who are engage with somebody.

Faculty of SHS. They will also benefit from the study. The findings of this research could be a springboard for classroom discussion to further enlighten the students on the challenges they might experience. They may also be prepared on how to handle the students with this kind of problem.

The Researcher. He will be enlightened of the lived experience of the teenage mother. The knowledge, skills, attitudes, and values that he will develop in the process of conducting the data gathering and writing the research paper will make him a better guidance associate. The lessons that he will learn from this task will make him a better team player in his present organization.

Future Researchers. They may make use the findings of this research. This research would add color to the local literature for a more in-depth investigation.

\section{Literature review}

\subsection{Teenage Pregnancy}

According to Jain et al. in their 2019 study entitled: Maternal outcome in teenage pregnancy published by Indian Journal of Obstetrics and Gynecology Research found out that the mothers' accounts reflected, 'ensuring health and safety of the fetus', and 'welcoming new lives with excitement', relying on family's assistance and support, and worrying about the impact of ART on health, 'ensuring health and safety of the fetus' Narratives around 'welcoming new lives with excitement' reflected four subthemes: overcoming hardship for worthwhile results, realizing one's life and dreams, proving to be fertile enough to give birth, and return to normal life track. 
In a study conducted by Wall-Wieler et al. in 2016 entitled: Teenage pregnancy, the impact of maternal adolescent childbearing and older sister's teenage pregnancy on a younger sister published by BMC Pregnancy Childbirth found out that Planning your pregnancy can help you have a healthy baby. Babies who are planned are more likely to be born healthy than babies who aren't planned. If you're planning to have a baby, you're more likely to get healthy before you get pregnant and to get early and regular prenatal care during pregnancy. Most unmarried teens don't plan on becoming pregnant, and they're often terrified when it happens. Many, particularly younger teens, keep the news of their pregnancies secret because they fear the anger and disappointment of their parents. Some might even deny to themselves that they are pregnant - which makes it even more important for parents to step in and find medical care for their teen as early in the pregnancy as possible. Younger teens' pregnancies, in particular, are considered high risk because their bodies haven't finished growing and are not yet fully mature. Some parents feel a sense of guilt, thinking that if only they'd done more to protect their child this wouldn't have happened. And although some parents are embarrassed by their teen's pregnancy and worried about how family, friends, and neighbors will react, others are happy about the news of a soon-to-be grandchild - especially if the teen is older and in a mature relationship.

In a collaborative study conducted by Salvador et al. published in 2016 entitled: The Phenomenon of Teenage Pregnancy in the Philippines published by European Scientific Journal found out parents' personalities also play a part in how they'll react. Some parents are easy to talk to or calmer in a crisis. Some are more emotional, more easily stressed out, more likely to get upset or angry, to yell or cry, or express themselves loudly. On the one hand, some parents felt embarrassed by their teen's pregnancy and worried about how family, friends and neighbor. Some of the parents know and their reaction were curious at their situation since they noticed lots of changes in their daughter. At the same time, after confirming the pregnancy at their age, it was dismayed on the part of the parents. The others are very disappointed since it happened at their age wherein their parents have lots of plans on them. Also, the expectations that their parents/families are giving to the child itself is actually one of the reasons that they felt that way. They really have to cope and adjust in order for them to face their situation. They have to listen on the advices that will be given by their parents or elders.

"Your overtired body may demand extra carbs now because they're easily metabolized, which helps keep energy levels up," says Dr. Goist (Lauren Wiener Updated February 24, 2020) According to Maria Carter article (February 25, 2020), on her published article stated that although Dr. Gaither notes mood swings as an early pregnancy symptom many women experience in the first six weeks, you're more likely to notice a missed period before this one. In a study conducted by Meherda et al. in 2017, it has found out that adolescent pregnancy is often describe as a major concern in public health and is associated with negative outcomes for educational and career attainment. Both pregnant and parenting adolescents aspired to provide a "better life" for their children that included finishing school and obtaining a career. An emergent theme is that the experience of pregnancy and parenting is transformative and may invoke a positive refocusing of life aspirations for educational and career attainment. However, social stigma and barriers exist that make achieving educational and employment opportunities difficult. The study findings indicate that pregnant and parenting adolescents need strong social support networks and practical tools to help harness their motivation and transcend social and material barriers to achieve their goals and aspirations.

In the study conducted by Amongin et al. in 2020 entitled: Time trends in and factors associated with repeat adolescent birth in Uganda: Analysis of six demographic and health surveys found out that parenting can be tough, but even more so if you are a teen parent. While you might think parenting will conflict with pursuing your dreams, you can stay true to your life's future. You can achieve the perfect career for you and your child's life. Teenage mothers have less possibility to finish their studies after engaging in early pregnancy. Taking care of the baby and providing financial assistance are challenges they encountered and tried to cope up with. The academic performance, the financial status and support of the family of teenage mothers determine if they can pursue their studies and achieve their dreams in life. Sex and sexuality education should not just be a concept but should be developed further as a complete discipline and much more research should be conducted to that regard. 
Additionally, in a study conducted by Sharma et al. published in 2020 entitled: Comparison of Outcome of Teenage Pregnancy with Non- teenage pregnancy published by Nepal Journal of Obstetrics and Gynaecology found out the positive impact of perseverance on a person's overall success; people with more grit are more likely to graduate high school, stay married, and keep a job. Your high-schooler has been building their ability to persevere their entire life by overcoming small obstacles along the way. Internal resilient qualities that teen mothers may possess need to be identified and promoted. The characteristics of social competence, such as problem solving, independence, and motivation are shown by resilient youth. The individuals who demonstrate these characteristics are more likely to have increased self-esteem and assumed parental responsibility.

Moreover, in a study conducted by Hadley, Alison published in 2020 entitled: Teenage pregnancy: strategies for prevention published by the Obstetrics, Gynaecology and Reproductive Medicine found out that women get pregnant, whether they are married or not, whether they are teenagers or adults. This is not a new phenomenon; it has been happening throughout history and the problem lies in how we deal with it. Supporting teens that become pregnant is the first step in promoting successful outcomes for the individuals. Support that promotes positive self- reflection and positive opportunities for the future are ways that can make a difference in the lives of teen mothers and the way they perceive themselves. The analysis revealed the diversity and the internal structure of paths of the experience and realization of early motherhood: from negating oneself as a responsible mother to accepting the role of mother.

\subsection{Synthesis}

All the reviewed literature and studies above serve as guide for the reference to present the emerging themes in the study. The materials will help the researcher in her discussion to clarify the problems investigated and the methods used in this study. In the study conducted by Jain et al. in their 2019 entitled: Maternal outcome in teenage pregnancy published by Indian Journal of Obstetrics and Gynecology Research found out that the mothers' accounts reflected, 'ensuring health and safety of the fetuses, and 'welcoming new lives with excitement', relying on family's assistance and support, and worrying about the impact of ART on health. In a collaborative study conducted by Salvador et al. published in 2016 entitled: The Phenomenon of Teenage Pregnancy in the Philippines published by European Scientific Journal and Maria Carter article (February 25, 2020), have almost the same findings in connection with their emotions and feelings. Some are more emotional, more easily stressed out, more likely to get upset or angry, to yell or cry, or express themselves loudly. On the one hand, some parents felt embarrassed by their teen's pregnancy and worried about how family, friends and neighbor.

On the other hand, feeling of a mental, physical, and financial toll on some would-be teen fathers. The situation is further compounded by the physical changes they experience. Providing the teenager with global support is essential. Both studies of Wall-Wieler et al. in 2016 and Hadley, Alison published in 2020, pointed out about the importance of planning and the realization of early motherhood. According to them, planning your pregnancy can help you have a healthy baby. Babies who are planned are more likely to be born healthy than babies who aren't planned. If you're planning to have a baby, you're more likely to get healthy before you get pregnant and to get early and regular prenatal care during pregnancy. The problem lies in how to deal with it, when the women get pregnant, whether they are married or not, whether they are teenagers or adults. This is not a new phenomenon; it has been happening throughout history. Supporting teens that become pregnant is the first step in promoting successful outcomes for the individuals.

In a study conducted by Meherda et al. in 2017 and Amongin et al. in 2020 often described as a major concern in public health and is associated with negative outcomes for educational and career attainment. Both pregnant and parenting adolescents aspired to provide a "better life" for their children that included finishing school and obtaining a career. An emergent theme is that the experience of pregnancy and parenting is transformative and may invoke a positive refocusing of life aspirations for educational and career attainment. While you might think parenting will conflict with pursuing your dreams, you can stay true to your life future, 
you can achieve the perfect career for you and your child's life. Teenage mothers have less possibility to finish their studies after engaging in early pregnancy. Taking care of the baby and providing financial assistance are challenges they encountered and tried to cope up with. The academic performance, the financial status and support of the family of teenage mothers determine if they can pursue their studies and achieve their dreams in life. Sex and sexuality education should not just be a concept but should be developed further as a complete discipline and much more research should be conducted to that regard.

\section{Method}

The researcher employed qualitative research, specifically the interpretative phenomenological approach (IPA). A qualitative research concerns with exploring the understandings, meanings, and interpretations that people and other group attribute to their social world (Creswell, 2014). In addition, Tuffour (2017) mentioned that IPA is a qualitative research approach. Qualitative research explores and understands the meanings people assign to their experiences. Furthermore, qualitative research seeks to understand the inside perspectives of the participants from the participants themselves. Moreover, qualitative research can be used to explore less known or less understood topics or phenomenon to help bring to the forefront unexpected knowledge. Furthermore, the approach is suitable when a detailed in-depth view of a phenomenon is needed to explore a complex process and to illuminate the multifaceted nature of human experience.

Participants - The researcher chose LCBA and other Senior High School Institution within the City of Calamba as its research locale. The researcher specifically chooses the location as it is more accessible to the researcher and to conduct the interview easily since the researcher is currently designated as guidance associate in one of the said schools, LCBA in particular. The mentioned institution also has the number of students which is suitable for the study since it has a senior high school department with some cases of teenage pregnancy. The researcher also would like to know if how the teenage mothers revealed stories affecting their performance academically. In the conduct of this qualitative research, the researcher used the purposeful random sampling. This was the most appropriate sampling for the study since this looked at a random sample and adds credibility to a sample when the potential sample is larger than one can handle. In addition, purposive sampling, also known as judgmental, selective, or subjective sampling, is a form of non-probability sampling in which researchers rely on their own judgment when choosing members of the population to participate in their surveys as according to Alchemer (2021). The study covered 5 senior high school students in the City of Calamba, ages 16 to 19 (participants A to E) who gave birth at the time of this study.

Instrument - In gathering pertinent information, the researcher used eight (8) guide questions which was used as semi-structured interview questions. The researcher sent the verbatim transcription to the participants to verify and confirm his/her statements. He utilized the following interview questions:

$>\quad$ What was your initial reaction upon knowing that you're pregnant?

$>$ How did you and your partner deal with the news of unexpected pregnancy?

$>$ How did your parents know that you're pregnant? What was their reaction?

$>$ What were some of the changes you experienced during your pregnancy; physically, emotionally, mentally, and socially?

$>$ How did you face or overcome the challenges of being a teenage mother?

$>\quad$ What are your plans now that at a young age you have become a mother?

$>\quad$ How do you plan in achieving of your goals?

$>\quad$ What lessons or values you learned from your experience? 
Validation of the Instrument - The researcher established the validity of the interviews by presenting to the research adviser and some experts along the field of specialization in research and in education. All comments were significant consideration. After integrating the significant ideas, suggestions and insights of the experts, the final draft of the instrument was made in accordance with the statement of the problem.

Data Gathering Procedure - The researcher secured a letter of endorsement from the Dean of Graduate Studies of Laguna College of Business and Arts to conduct study on the Senior High School Department in Calamba City. The researcher explained the purpose and objectives of the study to the identified participants before their approval and signed for their confirmation as participants of the study. As the participants agreed to their participation, the date, time and place, a thorough interview was conducted face-to-face using interview guide. During this pandemic, the interview was conducted via Zoom or google meet or other forms of social media. The interview was the integral part in the methodology of the study since it signified the meaningfulness of the experience in the perspective of the participants. The interview process included asking permission to record, summarizing notes and gathering comprehensive information, insights, feelings, encountered experiences, and answers based on the questions to be answered by the participants. After composing the overall "essence" of the phenomenon under study. The researcher then met again with the participants to verify the verbatim accounts they shared during the interview. The researcher performed it as the last step so that the participants themselves clarified and rectified their responses, so the validity of the essence was obtained, and thus its credibility was established.

Ethical Consideration - The ethical guidelines as specified in the Research Manual of the school was followed by the researcher, as those ethical considerations was carefully observed throughout this paper. The interview participated in voluntarily by the teachers and the lived experiences shared by them. The informed consent of the participants required the researcher to explain them the importance/significance and objectives of the study. The data and information gathered was kept in confidentially. The works of researchers of other authors were properly recognized. The researcher assured the participants' data was kept in confidential. To ensure the use of ethical procedures, the purpose of the research, procedures, and outcomes was explained to the participants. Since the participation in this study are of minor age, an informed consent from their parents will be secured. Interviews was conducted at their most convenient time. After transcription of the interview, the copy or the verbatim responses was sent to them for verification of their given statements. No question that can cast insult on the capabilities of the teachers was included in the sub - questions.

Treatment for Qualitative Data - After gathering all the needed data from the conducted interviews, the researcher transcribed the interviews verbatim with his selected student and use color-coding to take note of the responses. Afterwards, the researcher cited the relevant responses of the co-researchers, categorize them by cluster or exemplars aligned with the interview questions utilized by the researcher and organize them in tables. The researcher imparted his own observations of every co- researcher asked. The emerging themes was then identified and extracted from the similar responses per line. Detailed discussion and reflections was included after each table and theme.

\section{Findings}

Corollary Question Number 1. What themes emerged from the testimonies of the teenage mothers?

The following thematic charts provide the findings gathered through semi-structured interviews conducted with the eight participants on the ten (8) interview questions. When asked about the initial reactions of the participants upon knowing that they were pregnant, they have stated that it was with mixed emotions, it was like more of anxious of what will others and their parents' reaction and also happy since they will be a mother at a very young age. For instance, the reactions shared by the co-researchers were actually be what they would be feeling since it was happened at a very young age. Likewise, the lifetime responsibility that will be experienced at their age is one the things that they have to stand for. Reactions that they felt upon knowing that they are at that 
situation were not that easy considering the age at the same time on how do they make decisions in life. According to Jain et al. in their 2019 study entitled: Maternal outcome in teenage pregnancy published by Indian Journal of Obstetrics and Gynecology Research found out that the mothers' accounts reflected, 'ensuring health and safety of the fetus', and 'welcoming new lives with excitement', relying on family's assistance and support, and worrying about the impact of ART on health, 'ensuring health and safety of the fetus' Narratives around 'welcoming new lives with excitement' reflected four subthemes: overcoming hardship for worthwhile results, realizing one's life and dreams, proving to be fertile enough to give birth, and return to normal life track.

\section{Thematic Chart A}

\section{Mixed emotions}

\begin{tabular}{|c|c|c|}
\hline Participant & Responses & Subordinate Themes \\
\hline Participant 2 & $\begin{array}{l}\text { "Natakot po, na masaya, ang una pong nangibabaw ay yung sasabihin ng family po nmin. } \\
\text { mixed emotions din po, yun po ang nangibabaw keysa happiness. medyo disappointed din } \\
\text { po, gawa ng, syempre po hindi ko din naman inexpect agad" }\end{array}$ & Afraid \\
\hline Participant 5 & $\begin{array}{l}\text { "Ang nagging reaction ko po nung malaman ko na buntis ako ay natakot. Maraming } \\
\text { pumasok sa isip ko, isa na na dito kung paano ko sasabihin sa magulang ko at kung ano ang } \\
\text { mangyayari sa akin." }\end{array}$ & \\
\hline Participant 3 & $\begin{array}{l}\text { "Pressured. Pressured in a way that I'm the only one who is capable of learning, taking } \\
\text { care of my two siblings and generally the hope of the } \\
\text { ménage." }\end{array}$ & Pressured \\
\hline Participant 4 & $\begin{array}{l}\text { "2months napo When I found out na pregnant po ako Lockdown kasi non and akala ko po } \\
\text { kulang lang ako sa exercise kaya low blood ako at nandon yung dalawang reaction at } \\
\text { feelings. yung tipong disappointed ka sa sarili mo at the same time happy ako kasi may } \\
\text { baby na pala ako sa tummy ko". }\end{array}$ & $\begin{array}{l}\text { Happy and Quite } \\
\text { Disappointed }\end{array}$ \\
\hline
\end{tabular}

Interview Question 2: How did you and your partner deal with the news of unexpected pregnancy?

\section{Thematic Chart B}

Accepting the situation

\begin{tabular}{|c|c|c|}
\hline Participant & Responses & Subordinate Themes \\
\hline Participant 3 & $\begin{array}{l}\text { "We engaged into deep talks, the fact that having those situation is truly a serious } \\
\text { one". }\end{array}$ & Having deep talks \\
\hline Participant 2 & $\begin{array}{l}\text { "Nagusap po kami kung papaano at kalian naming sasabihin sa family side po namin. } \\
\text { tapos kapag may freetime po kami sa skul, nagpaplano po kami kung paano ang } \\
\text { gagawin namin." } \\
\text { "Follow up: Kailan nyo naisipan na eto ay ipagtapat sa parents nyo? ako po yung } \\
\text { iniintay nya magsabi, bale inabot po kc kami ng almost } 6 \text { months na po. Nag iipon pa po } \\
\text { ako ng lakas ng loob, hindi po nila nahalata kasi parehas silang may work, gabi na po } \\
\text { sila nauwi, naabutan na lang po nil ana kakain na po, tapos tutulog na po. Nagtataka na } \\
\text { lnh din po sila na medyo nataba na ako pero hindi po sila nagtatanong. dun po muna sa } \\
\text { side ng partner ko naming unang ipinagtapat, sa mama niya. ang nauna po ata } \\
\text { nakapansin ay ang lola ng partner ko., yun nagtanong na nagtanong na po. after isang } \\
\text { linggo po tsaka naming ipinagtapat sa side ko, kay mama, kasi iniintay ko pa rin po kasi } \\
\text { yung mga result ng mga entrance exam" }\end{array}$ & \\
\hline Participant 4 & $\begin{array}{l}\text { "thru videocall lang po kami nag usap nung time nayon paano kami makakasure na } \\
\text { preggy ako kasi } 2 \text { mnths delay nako. Lockdown po kasi non. Mahirap magbyhae pero } \\
\text { buti nalang at front liner ang step dad nya so nakapunta po agad sya dito sa bahay. } \\
\text { Break pa nga po kami that time nung lockdown pero before lockdown is kami pa po. } \\
\text { Then bumili napo kami ng PT para makasigurado if ganon nga. Then yun, positive. Pero } \\
\text { buti po ang mindset namin ng partner ko nung time na yon ay same lang na "ito na yon } \\
\text { kailangan na namin harapin to." Hindi or wala isa samin ang thinking is abortion. } \\
\text { Parehas kaming umiyak sa isa't isa. pareho kaming masaya. Nagplano narin po kami } \\
\text { ng time nayon paano namin sasabihin sa family ko kasi nasa abroad si mama and si } \\
\text { papa naman po wala na. yung kuya at bunso ko lang po na kapatid ang kasama ko sa } \\
\text { bahay. Sa side naman po nya, Mommy palang nya ang may alam nung time na yon." }\end{array}$ & Being responsible \\
\hline Participant 5 & $\begin{array}{l}\text { "Napagkasunduan naming ng magulang ko na magpatuloy pa rin ako ng pag aaral } \\
\text { kahit buntis ako at simula din noo ay doon na ako tumira sa boyfriend ko". }\end{array}$ & \\
\hline Participant 1 & $\begin{array}{l}\text { "gusto po nya ipalaglag. Tinanong ko po siya kung bakit nya } \\
\text { ipalalaglag.perotinanggap na rin po niya". }\end{array}$ & $\begin{array}{l}\text { Not accepted, later on } \\
\text { accepted }\end{array}$ \\
\hline
\end{tabular}

When asked about on how the participants and their partners deal with news of unexpected pregnancy, the participants were in unison in their responses emphasizing that they really planned the next thing that will actually happen in their lives. Those plans that they will have, most especially in dealing with letting their parents know their situation and the things that they will do in the future, is actually a big help for the both of them since they did it both at a very young age, they have to face all the consequences in life. They have to plan 
Mesa, R. D.

and think as one in order for them to face the challenges in their lives.

In a study conducted by Wall-Wieler et al. in 2016 entitled: Teenage pregnancy: the impact of maternal adolescent childbearing and older sister's teenage pregnancy on a younger sister published by BMC Pregnancy Childbirth found out that Planning your pregnancy can help you have a healthy baby. Babies who are planned are more likely to be born healthy than babies who aren't planned. If you're planning to have a baby, you're more likely to get healthy before you get pregnant and to get early and regular prenatal care during pregnancy. Most unmarried teens don't plan on becoming pregnant, and they're often terrified when it happens. Many, particularly younger teens, keep the news of their pregnancies secret because they fear the anger and disappointment of their parents. Some might even deny to themselves that they are pregnant — which makes it even more important for parents to step in and find medical care for their teen as early in the pregnancy as possible. Younger teens' pregnancies, in particular, are considered high risk because their bodies haven't finished growing and are not yet fully mature. Some parents feel a sense of guilt, thinking that if only they'd done more to protect their child this wouldn't have happened. And although some parents are embarrassed by their teen's pregnancy and worried about how family, friends, and neighbors will react, others are happy about the news of a soon-to-be grandchild - especially if the teen is older and in a mature relationship.

Interview Question 3: What was the reaction of your parents after knowing that you are pregnant?

\section{Thematic Chart C}

Negative at first

\begin{tabular}{|c|c|c|}
\hline Participant & Responses & Subordinate Themes \\
\hline Participant 2 & $\begin{array}{l}\text { "Na curious na po si mommy at nagkaroon na po ng lakas ng loob na magtanong. mga tanghali po } \\
\text { galing po siyang work, lagi po syang natingin sa tiyan ko, tapos yun po nagtanong na po siya. } \\
\text { nagusap po kaming dalawa, umamin na po ako, yun disappointed daw nga po siya gawa ng iba daw } \\
\text { po yung standard nila sa amin gawa ng honor student kami tapos ganun daw po ang nangyari, pero } \\
\text { wala daw namn po silag magagawa pero sinuportahan niya daw po kami as long as nagaaral pa din } \\
\text { kami., Kay mommy ko po sinabi dahil mas comportable po ako, iba po kasi yung feeling ko pag sa } \\
\text { mother parang mas maiintindihan. pag uwi ko po the same day ay ipinaalam ko na din kay daddy, } \\
\text { si mama po ang unang nagsabi, un lang din po ang sinabi ni papa, mag aral huwag gawing } \\
\text { hindrance nap ag may anak na ay hindi na magaaral. hindi po siya nagalit, umiyak po siya, yun } \\
\text { disappointed, habang may baby patuloy pa ring mag aral." }\end{array}$ & Dismayed \\
\hline Participant 3 & $\begin{array}{l}\text { "I actually told them when I'm already runing in } 5 \text { months of being pregnant. At first their reaction } \\
\text { was dismayed and fully regretted on me but when my baby arrived they loved me and my child } \\
\text { more." }\end{array}$ & \\
\hline Participant 5 & $\begin{array}{l}\text { "Hindi nagging madali para sa akin na sabihin sa aking mga magulang ang nangyari sa akin dahil } \\
\text { na rin sa takot pero tinulungan ako ng aking mga kaibigan at boufriend ko kung opaano ito } \\
\text { ipapaliwanag sa kanila, kaya sa bandang huli, natanggap na ito ng aking mga magulan"g }\end{array}$ & Accepted \\
\hline Participant 1 & $\begin{array}{l}\text { "Si mama po nagalit sa akin, isang araw lang naman po. Pero s papa, hindi naman nagalit. Gusto } \\
\text { na rin mag kaapo." } \\
\text { "Bakit daw po agad ako nabuntis, alam naman po nila na may boyfriend ako, napunta po siya dito } \\
\text { sa amin." }\end{array}$ & Mad \\
\hline Participant 4 & $\begin{array}{l}\text { "Gaya nga po ng sabi ko kanina nag plano po kaming dalawa ng partner ko paano namin } \\
\text { sasabihin. Pero nauna po namin sabihin sa kuya ko dahil don naging katulong namin si kuya } \\
\text { magsabi kay mama ng ayos. Ang reaction naman po ni mama syempre galit bakit hindi ko daw po } \\
\text { sinabi agad sa kanya e lagi naman kaming magka videocall. Eh hindi ko rin naman po alam na } \\
\text { preggy ako that time. Hindi po ako kinausap ni mama ng 1day pero inintindi ko nalang din po kasi } \\
\text { nanay yon and hindi ganon kadali matanggap kasi nga po bata pa kami". }\end{array}$ & \\
\hline
\end{tabular}

When asked about on how do their parents know and their reaction, they were unanimous that it was that their parent who were curious at their situation since they noticed lots of changes in their daughter. At the same time, after confirming the pregnancy at their age, it was dismayed on the part of the parents. Co-researchers stated that it was then very disappoint on the part of their parents, since it happened at their age wherein their parents have lots of plans on them. Also, the expectations that their parents/families are giving to the child itself is actually one of the reasons that they felt that way.

In a collaborative study conducted by Salvador et al. published in 2016 entitled: The Phenomenon of Teenage Pregnancy in the Philippines published by European Scientific Journal found out parents' personalities also play a part in how they'll react. Some parents are easy to talk to or calmer in a crisis. Some are more emotional, more easily stressed out, more likely to get upset or angry, to yell or cry, or express themselves loudly. 
On the one hand, some parents felt embarrassed by their teen's pregnancy and worried about how family, friends and neighbors would react.

Interview Question 4: What are some changes you experienced during pregnancy: physically, emotionally, mentally, and socially?

When asked about some changes, they experienced during pregnancy; physically, emotionally, mentally and socially, they were unison that they really experience the unusual ones. Changes that were actually different and was not experienced until they become pregnant. The participants had the same responses of experiencing those that was very unusual to them. Since they are really at a very young on that situation, they really have to cope and adjust in order for them to face their situation. They have to listen on the advices that will be given by their parents or elders.

\section{Thematic Chart D}

Very unusual

\begin{tabular}{|c|c|c|}
\hline Participant & Responses & Subordinate Themes \\
\hline Participant 5 & $\begin{array}{l}\text { "Maraming nagbago sa akin simula noong malaman ko na buntis ako tulad na lang dati } \\
\text { nagagawa koa kahit anong gusto ko kung gawin tulad ng pagsama sa mga kaibiogan ko di } \\
\text { tulad ngayon na na may anak na ako. mas kailangan ko siyang unahin kaysa ibang bagay. } \\
\text { responsibilidad mo bling isang magulang na alagaan siya at bantayan at kailangan mo din } \\
\text { magsikap para maibigay lahat ng pangangailangan niya." }\end{array}$ & $\begin{array}{c}\text { Can not socialize with } \\
\text { friends }\end{array}$ \\
\hline Participant 1 & $\begin{array}{l}\text { "Mga pagkain kagaya ng dinuguan, bayabas, santol ang gustong gusto kong kainin } \\
\text { (napapatawa) wala naman po kakaibang nabago physically sa akin. noon malapit na akong } \\
\text { manganak, may kakaiba akong naramdam. excited din po ako. naiisip ko po yung online } \\
\text { class, kc mahirap po mag alaga kapag nag oonline class. ayaw po kc sumama sa iba yung } \\
\text { baby ko. kaya hindi ko po nagagawa yung mga activities ko sa online. masaya din naman po } \\
\text { ang nga mga kaibigan ko. yung mga kaibigan ko po may mga anak na din sila". }\end{array}$ & Picky with food \\
\hline Participant 2 & $\begin{array}{l}\text { "Medyo tumataba po ako tapos yung sa paa ko po parang lagi po nilang pinupuna kapag } \\
\text { namamanas. pinapagalitan po ako, maglakadlakad daw po. mabilis po ako mairita, parang } \\
\text { gusto ko po nakukuha ko. sa paglilihi po, umaabot pa kaming manila para bumili ng pagkain. } \\
\text { inabutan po ng pandemic kaya dito lang po ako sa bahay, tapos nakakausap ko po yung mga } \\
\text { friends ko sa chat, tinatawagan po nila ako, nangumgumusta po, may nakakausap naman po } \\
\text { ako kaya medyo nagana po yung loob ko kapag may mga stressful time." }\end{array}$ & Gaining weight \\
\hline Participant 3 & $\begin{array}{l}\text { "Naturally I have gained so much weight but I didn't felt the symptoms of pregnancy. On } \\
\text { those all aspects, emotional aspect have had huge impact on me at the first moment of when I } \\
\text { knew that I'm pregnant" }\end{array}$ & \\
\hline Participant 4 & $\begin{array}{l}\text { "Madalas lang pong sumakit balakang ko non hehe. About sa pag uugali naman po, madalas } \\
\text { pong magalit and sobrang sensitive ko non. Ang bilis bilis kong masaktan sa mga bagay } \\
\text { bagay mabilis malungkot, mabilis umiyak. Sobrang madamdamin po ako that time. Madalas } \\
\text { ko nga pong awayin non partner ko tipong gusto ko syang paalisin lagi sa bahay. Pagdating } \\
\text { sa mga tao naman po sa paligid ko syempre hindi mawawala ang positive and negative } \\
\text { comments.." }\end{array}$ & Experiencing backpain \\
\hline
\end{tabular}

"Your overtired body may demand extra carbs now because they're easily metabolized, which helps keep energy levels up," says Dr. Goist (Lauren Wiener Updated February 24, 2020). According to Maria Carter article (February 25, 2020), on her published article stated that although Dr. Gaither notes mood swings as an early pregnancy symptom many women experience in the first six weeks, you're more likely to notice a missed period before this one. Feeling of a mental, physical, and financial toll on some would-be teen fathers. The situation is further compounded by the physical changes they experience. Providing the teenager with global support is essential.

Interview Question 5: How did you face or overcome the challenges of being a teenage mother?

When asked on how they face/overcome their challenges being a teenage mother, participants mentioned that they have to let their baby their inspiration. Likewise, thinking of what will be best for them and also for the baby is much more important than other things. They divulged that looking at the positive side of life will actually help them to overcome all the challenges they have in life. Also, it will help them to get back on their feet in spite of the unwanted pregnancy. Making their baby their inspiration in working harder in order to achieve their dreams is one of things that they have to have first in their minds. 
Mesa, R. D.

\section{Thematic Chart E}

Looking at the brighter side

\begin{tabular}{|c|c|c|}
\hline Participant & Responses & Subordinate Themes \\
\hline Participant 1 & $\begin{array}{l}\text { "ngayon po nagkaroon na ako ng baby, kailangan ko pang magsumikap at tuparin yung } \\
\text { mga dapat tuparin po sa anak ko. sap ag aaral po, ang plano po ni mama ay mag module na } \\
\text { lang daw po ako." }\end{array}$ & Being Hardworking \\
\hline Participant 4 & $\begin{array}{l}\text { "Syempre bilang isang teen age mom nandon yung tanong ko sa sarili ko na } \\
\text { "paano/saan ko sisimulan?" "Ano yung mga bagay na kaya kong gawin kahit } \\
\text { na buntis ako?" "Ano yung nga bagay na gagawin ko para hindi ako magaya } \\
\text { sa mga nabuntis na umaasa sa magulang" Nung time nayon, ilang weeks bago ako at yung } \\
\text { partner ko gumawa ng paraan kasi lockdown hindi naman po kami makakapag work outside } \\
\text { or miski yung partner ko. Ako po yung unang nakaisip why not mag try kami mag benta ng } \\
\text { preloved clothes. Mag try kami mag live sa facebook and ayun po di namin expect na mag } \\
\text { buboom yung live na namin yon. Magaling din po kasi mag live selling yung partner ko } \\
\text { hahaha. hanggang sa okay naman po, Tinuloy tuloy na namin. Dun po nagsimula kami } \\
\text { kumita ng kumita ng sarili naming pera. Pangkain or pang ambag sa bahay sinasagot namin. } \\
\text { Minsan samin papo umuutang kasama namin sa bahay. Miski sa checkup ko at pangbili ng } \\
\text { mga gatas at gamot ko pang buntis hindi po namin hiningi sa parents namin. Pati narin mga } \\
\text { gamit ni baby. Crib, damit, paliguan etc.. Miski panganganak ko kami pong mag partner ang } \\
\text { nabayad ng bills sa ospital galing sa ipon namin sa business. at yun po ang kinaproud ko sa } \\
\text { sarili at sa partner ko. Hindi kami naging pabigat sa bahay at yun ang gusto namin mangyari } \\
\text { na hindi porket buntis or nagkaroon ng baby is pabigat or wala na kaming magagawa." }\end{array}$ & \\
\hline Participant 2 & $\begin{array}{l}\text { "lagi ko na lang po tinitingnan yung mga bagay na positive, hindi po ako nagiisip ng mga } \\
\text { negative na bagay po. kasi po medyo nadadown po ako, kapag hindi ko po kaya, lalo po } \\
\text { akong nadadown kapag yung mga nasa paligid ko po ay kung ano no pa pong sinasabi kaya } \\
\text { tinitingnan ko na lang po na help po sa akin par maovercome ko po yung mga challenge ko." } \\
\text { "MY Partner... lagi po syang taga cheer up, para kaopag malungkot po ako, lagi lang po } \\
\text { nagpapatawa, hindi po siya yung kapag may problema, paguusapan pong Mabuti, palaging } \\
\text { buhay, huwag po masyado dibdibin ang mga bagy bagay" }\end{array}$ & Being Optimistic \\
\hline Participant 3 & $\begin{array}{l}\text { "Basically I overcome it by realizing that life must go on. It doesn't matter how hard being } \\
\text { a teenage mom but what matter is you continue your role as a daughter, as an oldest sister } \\
\text { and especially embracing what life gives you." }\end{array}$ & \\
\hline Participant 5 & $\begin{array}{l}\text { "Hindi madali sa akin ang maging isang batang ina lalo na noong time na napasok ako. } \\
\text { Kahit buntis ako napapasok ako. Kase minsan hindi mo maiwasan na makarinig sa ibang tao } \\
\text { na masasakit na salita. Maraming pagsubok. ang dumating pero hindi yun nagging hadlang } \\
\text { para sumuko ka dahil naisip ko magkakaanak na ako kaya yun ginagawa ay para sa } \\
\text { kanya.nagkaroon ako ng insperasyon bukod sa mga magulang ko kundi para sa anak ko." }\end{array}$ & \\
\hline
\end{tabular}

In a study conducted by Meherda et al. in 2017 it has found out that adolescent pregnancy is often described as a major concern in public health and is associated with negative outcomes for educational and career attainment. Both pregnant and parenting adolescents aspired to provide a "better life" for their children that included finishing school and obtaining a career. An emergent theme is that the experience of pregnancy and parenting is transformative and may invoke a positive refocusing of life aspirations for educational and career attainment. However, social stigma and barriers exist that make achieving educational and employment opportunities difficult. The study findings indicate that pregnant and parenting adolescents need strong social support networks and practical tools to help harness their motivation and transcend social and material barriers to achieve their goals and aspirations.

Interview Question 6. What are your plans now that at a young age you have become a mother?

When asked on the plans now that at a young age they have become a mother, co- researchers were unison in stating that though they got pregnant at a very young age, still they have to pursue their dreams and their goals in life. Participants were synonymous with each other that they still have continue what life gave to them. They still have to make plan on every decision that they have to make and be sure that it will be best not only for them but also for the future of the baby. That though they had that situation still they can prove themselves to others that they are that kind that have the courage to believe and pursue their dream in life.

In a collaborative study conducted by Amongin et al. in 2020 entitled: Time trends in and factors associated with repeat adolescent birth in Uganda: Analysis of six demographic and health surveys found out that parenting can be tough, but even more so if you are a teen parent. While you might think parenting will conflict with pursuing your dreams, you can stay true to your life ... future, you can achieve the perfect career for you and your child's life. Teenage mothers have less possibility to finish their studies after engaging in early 
pregnancy. Taking care of the baby and providing financial assistance are challenges they encountered and tried to cope up with. The academic performance, the financial status and support of the family of teenage mothers determine if they can pursue their studies and achieve their dreams in life. Sex and sexuality education should not just be a concept but should be developed further as a complete discipline and much more research should be conducted to that regard.

\section{Thematic Chart F}

Pursuing their dreams

\begin{tabular}{|c|c|c|}
\hline Participant & Responses & Subordinate Themes \\
\hline Participant 1 & $\begin{array}{l}\text { "makahanap po ng trabaho para po paglaki ng anak ko may maibibgay ako sa kanya, pwede } \\
\text { ko naman pong pagsabayin, kung kakayanin po." }\end{array}$ & Finding a Job \\
\hline Participant 4 & $\begin{array}{l}\text { "as of now, Ang tanging plano ko lang po muna or focus kopo is magkaroon ng pera para } \\
\text { walang masabi ang mga tao. Nabubuhay namin si baby sa sarili naming ipon/pera at the same } \\
\text { time nakakapag bigay po kami sa bahay. Plano kolang din po is mapalago ko yung business } \\
\text { na meron ako ngayon. Hindi lang para kay baby para din po saaming pamilya. Nagpaplano } \\
\text { din po kami magipon ngayon ng malaki para magkaroon kami ng sariling bahay. Para narin } \\
\text { sa binyag at birthday ng baby namin." }\end{array}$ & \\
\hline Participant 2 & $\begin{array}{l}\text { "Yun po, patuloy pa rin po akong mag aaral, tapos nadagdagan po yung motivation ko, yung } \\
\text { willingness ko po na magsipag po lalo, tapos feeling ko po ma aachive ko po kapag may mas } \\
\text { dahilan po yung bagay na gusto ko" }\end{array}$ & Finishing my Studies \\
\hline Participant 3 & $\begin{array}{l}\text { "My one and only plan is to continue my study up until I become one of the Accountants } \\
\text { because every step of the moment, my child gives me the reason to pursue every single step } \\
\text { of my goals." }\end{array}$ & \\
\hline Participant 5 & $\begin{array}{l}\text { "Ang plano ko ay makapagtapos pa rin ng pag aaral para balang araw may maipakita ako sa } \\
\text { ank ko kahit maaga siyang dumating. Nagtapos parin ako para sa kanya at makahanap ako ng } \\
\text { magandang trabaho para sa kanya para maibigay ko lahat ng mga pangangailangan niya." }\end{array}$ & \\
\hline
\end{tabular}

Interview Question 7. How do you plan in achieving of your goals?

\section{Thematic Chart G}

\section{Perseverance and commitment}

\begin{tabular}{|c|c|c|}
\hline Participant & Responses & Subordinate Themes \\
\hline Participant 1 & $\begin{array}{l}\text { "pagsisikap lng po, makapag aral lang po, makasama po ang family po at makaka } \\
\text { bonding sila. maging regular sa trabaho. wala png plano magpakasal. (napatawa)" }\end{array}$ & Continue being Hardworking \\
\hline Participant 4 & $\begin{array}{l}\text { "Step by step ang bawat plano. Tska para sakin po hindi lang dapat puro } \\
\text { planoHindi naman po mawawala ang edukasyon. Maaaring malate kami sa mga } \\
\text { kasabayan po namin, pero mas uunahin kopo muna ang dapat unahin. Pagdating sa } \\
\text { pangarap hindi naman po ako yung tipo ng tao na may mindset or mataas yung mga } \\
\text { pangarap sa buhay. na dapat sa ganitong age kailangan ko na maging ganito, ganyan. } \\
\text { Na Dapat ganito ako pag laki ko. Dapat mapuntahan ko to. Ako po kasi yung tipo ng } \\
\text { tao na basta matyaga ka at madami kang gustong gawin, gawin mo nalang. Pag } \\
\text { sipagan mo. Bonus pa if yung simpleng kagustuhan ko is madagdagan pa. Malate } \\
\text { man sa mga bagay bagay wala napo yun sakin yun as long as nagagawa namin yung } \\
\text { responsibilidad namin ngayon bilang isang magulang na." }\end{array}$ & \\
\hline Participant 5 & $\begin{array}{l}\text { "Unang una kailngan ko munang makapag tapos ng pag aaral at makahanap ng } \\
\text { mayos na trabaho para sa anak ko at maibigay lahat ng pangangailangan niya kahit } \\
\text { hindi iyon madali". }\end{array}$ & \\
\hline Participant 2 & $\begin{array}{l}\text { "SA pagpaplano po, parang high standard po. ang tinitingnan na po namin ay yung } \\
\text { kakalabasan hindi po yung sa process, pero tinitake po naming yung bawat process } \\
\text { ng mabuti, pinag iisipan po. ang lahat pong bagay pinag iisipang mabuti bago po } \\
\text { naming iactual } \\
\text { para po ma attain yung goal na gusto po naming" }\end{array}$ & Setting High Standards \\
\hline Participant 3 & $\begin{array}{l}\text { "Basically, goals can achieve base on the achiever, therefore if you don't persevere } \\
\text { you will not achieve your endeavors." }\end{array}$ & \\
\hline
\end{tabular}

When asked on the plans in achieving their goals, they were unanimous in stating that it was perseverance and commitment that is needed. Knowing that you already that they have plans but still they have these that was mentioned as a help in achieving goals. The participants' answer was synonymous with each other that they have to have perseverance and commitment. Those two were important since they have to let themselves prove that what others thinking on them is wrong. Though they had encounter that situation still, they have to continue.

In a study conducted by Sharma et al. published in 2020 entitled: Comparison of Outcome of Teenage Pregnancy with Non- teenage pregnancy published by Nepal Journal of Obstetrics and Gynaecology found out the positive impact of perseverance on a person's overall success; people with more grit are more likely to 
Mesa, R. D.

graduate high school, stay married, and keep a job. Your high-schooler has been building their ability to persevere their entire life by overcoming small obstacles along the way. Internal resilient qualities that teen mothers may possess need to be identified and promoted. The characteristics of social competence, such as problem solving, independence, and motivation are shown by resilient youth. The individuals who demonstrate these characteristics are more likely to have increased self-esteem and assumed parental responsibility.

Interview Question 8: What lessons or values you learned from your experience?

When asked on the lessons or values that they have learned from the experiences, co- researchers were unanimous that they have to be mindful in every action that they are about to make in life. Knowing first the pros and cons, is a big help in making decisions in life. Being mindful on every action that you are going to make is a big help in decision making as well. Aside from letting to think if you are going to push through it or not, you can actually have the chance to think of the possible consequences on the actions that you are about to make. More so, letting you know that you always have to think on your limitations.

\section{Thematic Chart H}

Thinking before doing

\begin{tabular}{|c|c|c|}
\hline Participant & Responses & Subordinate Themes \\
\hline Participant 2 & $\begin{array}{l}\text { "Be mindful po, for every little thing po na ginagawa po naming, as a young po, gusto po } \\
\text { naming mag enjo enjoy lang po pero inaalam po naming yung bawat bagay na magiging } \\
\text { dulot po sa amin kasi po hindi po lahat ng mali, makakaya pong itama, kaya po kailangan } \\
\text { po maging mindful po sa bawat ginagawa naming" } \\
\text { "To others: maging open po sa family palagi para hindi po mahirapan, kapag may } \\
\text { problem ana mabibigla po sila, kaya lagi pong yung communication, yung connection po } \\
\text { dapat po dikit na dikit hindi po yung nakikipag agwan" } \\
\text { "To with partner: enjoy lang po dapat, wag madaliin ang mga bagay bagay kasi po } \\
\text { marami po pagbabago ang mangyayari" }\end{array}$ & Be Mindful \\
\hline Participant 3 & $\begin{array}{l}\text { "I learned that everything happens for a reason but I always set on your mind that if you } \\
\text { are not fully ready emotionally, physically, spiritually and even finacially don't do the same } \\
\text { thing around." }\end{array}$ & $\begin{array}{c}\text { There's a Reason } \\
\text { behind }\end{array}$ \\
\hline Participant 4 & $\begin{array}{l}\text { "Natutunan kopo kung paano lalo mag sumikap. Natutunan ko kung paano or gaano } \\
\text { kahirap yung responsibilidad at gawain ng isang magulang na. Nandon na yung limit, } \\
\text { Nandon na yung dapat at hindi dapat mong gawin. Natutunan ko paano lalo magkaroon ng } \\
\text { mahabang pasensya sa mga bagay. Ngayon, natututo at tinututo kopo ang sarili ko maging } \\
\text { mabuting ina at asawa sa sarili kong pamilya." }\end{array}$ & Being Responsible \\
\hline Participant 5 & $\begin{array}{l}\text { "Ang natutunan kong lesson about sa nagging experience ko ay marami tulad na lang na } \\
\text { magdesisyon ka hindi na para sa sarili mo kundi para sa ikabubuti ng pamilya mo. Matuto } \\
\text { ng magsakripisyo at tumayo sa sarili mong mga paa, himndi mon a kailangang umasa sa } \\
\text { magulang mo kahit hindi ito madali at kailangan mo ng tanggapin ang pagbabago sa buhay } \\
\text { mo isa ng ina. At kailangan mon a matutunang maging isang mabuting magulang para na } \\
\text { sa anak mo." }\end{array}$ & \\
\hline
\end{tabular}

In a study conducted by Hadley published in 2020 entitled "Teenage pregnancy: strategies for prevention" published by the Obstetrics, Gynaecology and Reproductive Medicine found out that women get pregnant, whether they are married or not, whether they are teenagers or adults. This is not a new phenomenon; it has been happening throughout history and the problem lies in how we deal with it. Supporting teens that become pregnant is the first step in promoting successful outcomes for the individuals. Support that promotes positive self- reflection and positive opportunities for the future are ways that can make a difference in the lives of teen mothers and the way they perceive themselves. The analysis revealed the diversity and the internal structure of paths of the experience and realization of early motherhood: from negating oneself as a responsible mother to accepting the role of mother. Conclusions The final result is constituted by the model revealing the transformation of teenage motherhood and mechanisms underlying it.

Corollary Question Number 2. Based on the findings, what guidance program may be proposed?

Based from the findings of the study the proposed program has been created. This action plan for senior high school department is consist of different activities that cover the whole semester. Such activities/ program will help enough to spread awareness and create necessary action for each issues/ problem that may arise. The researcher also come up with the creation of a Facebook Page with account name Gender and Development. This 
page focuses on the different gender opportunities, challenges, problems and issues and seeks to achieve gender equality. A series of webinars about some issues regarding sex education, early and unintended pregnancy and other related topics with regards to some gender issues.

The Proposed Guidance Program

\begin{tabular}{|c|c|c|c|c|c|}
\hline Area Of Concern & Objectives & Activities Or Strategies & Time Frame & Person Involved & Success Indicators \\
\hline $\begin{array}{l}\text { 1. Individual Inventory } \\
\text { Service }\end{array}$ & $\begin{array}{l}\text { To continuously process } \\
\text { the accumulation, } \\
\text { recording and utilizing } \\
\text { information on each } \\
\text { student for guidance } \\
\text { and counseling } \\
\text { purposes and for } \\
\text { obtaining a complete } \\
\text { picture of the } \\
\text { individual }\end{array}$ & $\begin{array}{l}\text { Updating of Students' } \\
\text { Individual Inventories }\end{array}$ & $\begin{array}{l}\text { August- September } \\
2021\end{array}$ & $\begin{array}{l}\text { Guidance Personnel } \\
\text { Students }\end{array}$ & $\begin{array}{l}90-95 \% \text { of students } \\
\text { were able to fill out the } \\
\text { individual inventory } \\
\text { form }\end{array}$ \\
\hline 2. Guidance Hour & $\begin{array}{l}\text { To provide assistance, } \\
\text { support and facilitates } \\
\text { all students in } \\
\text { developing and } \\
\text { managing them } \\
\text { individual personal, } \\
\text { social, educational, and } \\
\text { career goals and plans } \\
\text { to create a venue for } \\
\text { self-improvement }\end{array}$ & $\begin{array}{l}\text { Weekly meeting with the } \\
\text { student }\end{array}$ & $\begin{array}{l}\text { Every Assessment Day } \\
\text { August 2021- May } \\
2022\end{array}$ & $\begin{array}{l}\text { Guidance Associate, } \\
\text { Adviser, Students }\end{array}$ & $\begin{array}{l}90 \% \text { students' } \\
\text { attendance }\end{array}$ \\
\hline \multirow[t]{4}{*}{ 3. Counseling Service } & $\begin{array}{l}\text { To provide early } \\
\text { intervention and } \\
\text { responding to students } \\
\text { who are experiencing } \\
\text { immediate on-going } \\
\text { problems, concerns, or } \\
\text { crises which interfere } \\
\text { with their learning }\end{array}$ & $\begin{array}{l}\text { Home Visitation and } \\
\text { Follow-up }\end{array}$ & $\begin{array}{l}\text { Open Schedule/As need } \\
\text { rises }\end{array}$ & $\begin{array}{l}\text { Guidance Associate, } \\
\text { Adviser, Student and } \\
\text { Guardians }\end{array}$ & $\begin{array}{l}90 \% \text { on the referral list } \\
\text { were able to follow up } \\
\text { and visited their home }\end{array}$ \\
\hline & $\begin{array}{l}\text { Provide opportunity for } \\
\text { the instructors to refer } \\
\text { students with } \\
\text { behavioral and } \\
\text { academic difficulties }\end{array}$ & Referrals & All Year Round & $\begin{array}{l}\text { Guidance Associate, } \\
\text { Senior High School } \\
\text { Students }\end{array}$ & $\begin{array}{l}90 \%-95 \% \text { were } \\
\text { referred and attest } \\
\text { their behavioral and } \\
\text { academic difficulties }\end{array}$ \\
\hline & $\begin{array}{l}\text { To spread awareness on } \\
\text { the effect of the early } \\
\text { pregnancy and its } \\
\text { consequences }\end{array}$ & $\begin{array}{l}\text { Webinar on Early and } \\
\text { Unintended Pregnancy }\end{array}$ & $\begin{array}{l}\text { October } 2021 \\
\text { And April } 2022\end{array}$ & $\begin{array}{l}\text { 3.4 Guidance } \\
\text { Associate and } \\
\text { Students }\end{array}$ & $\begin{array}{l}90 \%-95 \% \text { students' } \\
\text { attendance }\end{array}$ \\
\hline & $\begin{array}{l}\text { Awareness training, } \\
\text { information, and a call } \\
\text { to action for parents and } \\
\text { guardian. }\end{array}$ & $\begin{array}{l}\text { Sex Education Online } \\
\text { Symposium }\end{array}$ & November 2021 & $\begin{array}{l}\text { Guidance Associate } \\
\text { and Parents and } \\
\text { Guardians }\end{array}$ & $\begin{array}{l}90 \%-95 \% \text { students' } \\
\text { attendance }\end{array}$ \\
\hline 4. Placement Program & $\begin{array}{l}\text { Help find out what } \\
\text { course/ career suits the } \\
\text { students and be } \\
\text { prepared for the } \\
\text { challenge of excelling } \\
\text { in future career }\end{array}$ & Job Conference & May 2022 & $\begin{array}{l}\text { Guidance Associate } \\
\text { and students }\end{array}$ & $\begin{array}{l}90 \%-95 \% \text { students' } \\
\text { attendance }\end{array}$ \\
\hline
\end{tabular}

\section{Conclusion}

This phenomenological study looked into the lived experiences of teenage mothers in the City of Calamba. The semi-structured interview of these co-researchers focused on their initial reaction upon kowing that they're pregnant. The co-researchers were unanimous in their answers they have stated that it was with mixed emotions, it was like more of anxious of what will others and their parents' reaction and also happy since they will be a mother at a very young age.

When asked about on how the participants and their partners deal with news of unexpected pregnancy, the participants were in unison in their responses emphasizing that they really planned the next thing that will 
actually happen in their lives. Meanwhile, in terms on how did the parents know that they are pregnant and their reaction, the participants revealed that it was that their parent who were curious at their situation since they noticed lots of changes in their daughter. At the same time, after confirming the pregnancy at their age, it was dismayed on the part of the parents. However as regards to some changes they experienced during pregnancy; physically, emotionally, mentally and socially, they were unison that they really experience the unusual ones. Changes that were actually different and was not experienced until they become pregnant.

With regards to how they face or overcome the challenges of being a teenage mother, co- researchers mentioned that they have to let their baby their inspiration. Likewise, thinking of what will be best for them and also for the baby is much more important than other things. However, in terms of plans now that at young age they have become a mother, co-researchers were unison in stating that though they got pregnant at a very young age, still they have to pursue their dreams and their goals in life. Meanwhile, in terms of the plans in achieving the goals, they were unanimous in stating that it was perseverance and commitment that is needed. Knowing that you already that they have plans but still they have these that was mentioned as a help in achieving goals. The co-researchers' answer were synonymous with each other that they have to have perseverance and commitment. Consequently, the lessons or values they learned from the experience; co-researchers were unanimous that they have to be mindful in every action that they are about to make in life.

For instance, the reactions shared by the co-researchers were actually be what they would be feeling since it was happened at a very young age. Likewise, the lifetime responsibility that will be experienced at their age is one the things that they have to stand for. Reactions that they felt upon knowing that they are at that situation were not that easy considering the age at the same time on how do they make decisions in life. Those plans that they will have, most especially in dealing with letting their parents know their situation and the things that they will do in the future, is actually a big help for the both of them since they did it both at a very young age, they have to face all the consequences in life. They have to plan and think as one in order for them to face the challenges in their lives.

Co-researchers stated that is were then very disappointed on the part of their parents, since it happened at their age wherein their parents have lots of plans on them. Also, the expectations that their parents/families are giving to the child itself is actually one of the reasons that they felt that way. The participants have the same responses of experiencing those that was very unusual to them. Since they are really at a very young on that situation, they really have to cope and adjust in order for them to face their situation. They have to listen on the advices that will be given by their parents or elders.

Co-researchers were synonymous with each other that they still have continue what life gave to them. They still have to make plan on every decision that they have to make and be sure that it will be best not only for them but also for the future of the baby. That though they had that situation still they can prove themselves to others that they are that kind that have the courage to believe and pursue their dream in life. Knowing first the pros and cons, is a big help in making decisions in life. Being mindful on every action that you are going to make is a big help in decision making as well. Aside from letting to think if you are going to push through it or not, you can actually have the chance to think of the possible consequences on the actions that you are about to make. More so, letting you know that you always have to think on your limitations. Those two were important since they have to let themselves prove that what others thinking on them is wrong. Though they had encountered that situation still, they have to continue.

They also divulged that looking at the positive side of life will actually help them to overcome all the challenges they have in life. Also, it will help them to get back to their normal life though they have done that unwanted pregnancy. Making their baby their inspiration in working harder in order to achieve their dreams is one of things that they have to have first in their minds.

Being a mother is such a precious gift from God. It requires a lot of patience, dedication and hard work in order to accomplished the role of being a mother. But in this situation, at their young age, they already

58 Consortia Academia Publishing (A partner of Network of Professional Researchers and Educators) 
experience to become a mother. Unintended pregnancy occurred because of curiosity. The co-researchers experienced mixed emotion when they found out that they are pregnant. They also manifested some changes physically, emotionally and socially. At their young age, they already have their plans about their future, about their family. With the guidance of their parents, whom upon knowing that they are pregnant, got angry but later on accepted their situation and supported them until they gave birth. With all these experiences, which they just learned along the way simply define that being a mother did not require an age but rather, it requires compassion, dedication, acceptance and hard work.

\subsection{Recommendations}

Based on the consolidated findings and reflections, the following recommendations are offered:

$>$ For the teenage parents, they may be responsible enough in their life most especially right now since they become parents at early age and to accept the full responsibility of being very young parents.

$>$ For the parents, they may practice more open communication with their children.

$>$ They may properly guide their children in all aspects of life despite of a hectic schedule. They may be a very supportive one to their children for them to feel that they have to show the best every day.

$>$ For the schools, they may incorporate topics such as Sex Education or topics that are related with the aforementioned issues, for our students to be more aware most especially in gender and development. They may provide that may explain and elaborate well the said subject. Values formation is still the number one priority of educational institution for the benefit of their stakeholders.

$>$ For the guidance associates, they may conduct seminars for students to be more aware. They may give additional number of hours in counselling for students so that they'll be still guided though they are at school. Inclusion of "guidance counselor's time" within the class schedule of the students may be part of their daily routine, wherein students may ask their queries on certain topics that they felt important and sensitive towards their development such as teenage pregnancy.

$>$ For teenagers, they may focus more on study instead of others things. They may know the pros and cons on every decision that they are about make in life. That the issue on teenage pregnancy may serve as an eye-opener for them that this happens if you are not thinking critically.

$>$ For Support System, they may give advice that will help each one of them develop holistically. They may serve as a role model for each other. They may not tolerate other's wrong doings.

$>$ The output that this study can be utilized by Guidance Departments and serve as an eye-opener for the students and even the parents. They can utilize this so that they would be more aware on the essence the Sex Education and would let them think before doing or making decisions in life.

For future researchers, they may conduct similar researches which can come up with a correlational type of research which relates to the problem that was tackled by the researcher.

\section{References}

Akella, D., \& Jordan, M. (2011). Impact of social and cultural factors on teen pregnancy. J Health Dispar Res Pract, 8, 41-62.

Arceo-Gomez, E., \& Campos-Vazquez, R. (2014). Teenage pregnancy in Mexico: Evolution and consequences. Latin American Journal of Economics, 51(1), 109-146.

Black, K. (2009). Impact of demographic factors, early family relationships and depressive symptomatology in teenage pregnancy. Australian \& New Zealand Journal of Psychiatry, 38(4), 197- 204.

Chandra-Mouli, V., Plesons, M., Hadley, A., Maddaleno, M., Oljira, L., Tibebu, S., Akwara, E., \& Engel, D. 
Mesa, R. D.

(2019). Lessons learned from national government- led efforts to reduce adolescent pregnancy in Chile, England and Ethiopia. Early Childhood Matters.

Darroch, J., Woog, V., Bankola, A., \& Ashford, L. (2016). Adding it up: costs and benefits of meeting the contraceptive needs of adolescents. New York, Guttmacher Institute.

East, P. L., Reyes, B. T., \& Horn, E. J. (2007). Association between adolescent pregnancy and a family history of teenage births. Perspectives on Sexual and Reproductive Health, 39(2), 108-115.

Jackson, C. A., Henderson, M., Frank, J. W., \& Haw, S. J. (2012). An overview of prevention of multiple risk behavior in adolescence and young adulthood. J Public Health, 34(1), 31-40.

Mann, E. S., Cardona, V., \& Gómez, C. A. (2015). Beyond the discourse of reproductive choice: Narratives of pregnancy resolution among Latina/o teenage parents. Culture, Health \& Sexuality, 17(9), 1090-1104. https://doi.org/10.1080/13691058.2015.1038853

Maticka-Tyndale, E., Wildish, J., \& Gichuru, M. (2010). Thirty-month quasi-experimental evaluation follow up of a national primary school HIV intervention in Kenya. Sex Education, 10(2), 113-130.

McCall, S. J., Bhattacharya, S., Okpo, E., \& Macfarlane, G. J. (2015). Evaluating the social determinants of teenage pregnancy: A temporal analysis using a UK obstetric database from 1950 to 2010. Journal of Epidemiology and Community Health, 69(1), 49. https://doi.org/10.1136/jech-2014-204214

Mukhopadhyay, P., Chaudhuri, R. N., \& Paul, B. (2010). Hospital based perinatal outcomes and complications in teenage pregnancy in India. Journal of Health, Population and Nutrition, 28(5), 494-500.

Neal, S., Matthews, Z., Frost, M., Fogstad, H., Camacho, A. V., \& Laski, L. (2012). Child bearing in adolescents aged 12-15 years in low resource settings: A neglected issue - new estimates from demographic and household surveys in 42 countries. Acta Obstet Gynecol Scand, 91(9), 111401118.

Qureshi, F. (2018). The nation: Importance of sex education. Retrieved from https://nation.com.pk/26-Feb-2018/importance-of-sex-education

Sustainable Development Goals Knowledge Platform: Progress and information. (2019). https://sustainabledevelopment.un.org/sdg3

UN DESA, Statistics Division. Sustainable Development Goals Indicators. Global Database. (2017). New York, UNDESA. 